\title{
CONSEQÜÈNCIES DE LA PRECARIETAT EN LA PARTICIPACIÓ JUVENIL
}

IGNACIO MORA GUIJARRO Màster en Joventut i Societat Universitat de Girona ignacio.mora.guijarro@gmail.com https://orcid.org/0000-0002-3447-3725

Resum. La joventut està marcada per la precarietat des de les últimes dècades, i de manera més acusada des de l'inici de la crisi de 2008 , una crisi de la qual les persones joves no es van recuperar i que s'ha concatenat amb la crisi de la Covid-19, la qual cosa ha generat un estat permanent de dependències econòmiques, inestabilitat laboral, atur i insuficiència d'ingressos. A aquest fet, unit a la poca incidència de les polítiques de joventut per millorar les seues condicions de vida, té un impacte en el desenvolupament personal i social de les persones joves. A partir d'una anàlisi de la situació socioeconòmica i de les polítiques públiques respecte a les persones joves, en l'àmbit geogràfic del País Valencià, identifiquem les conseqüències que operen i que dificulten a la joventut involucrar-se en la vida pública, i participar en la societat, amb els perills que això comporta per a la democràcia.

PARAULES CLAU: joventut; precarietat; participació; democràcia; ciutadania. 
THE EFFECTS OF PRECARIOUSNESS ON PARTICIPATION AMONG THE YOUNG

ABSTRACT. Young people have been badly affected by precariousness in recent decades, even more intensely so since the beginning of the 2008 crisis, a crisis from which young people have not been able to recover and which has been seamlessly succeeded by the COVID-19 crisis, thus generating a permanent state of financial dependence, job instability, unemployment and low incomes for young people. This, together with the minimal effect that policies aimed at young people have on improving their living conditions, has had an impact on the personal and social development of young people. Starting with an analysis of the socio-economic situation and public policies regarding young people, we identify the outcomes that make it difficult for young people to get involved in public life, and participate in society, and highlight the dangers that these phenomena spell for democracy.

KEYWORDs: youth; precariousness; participation; democracy; citizenship. 


\section{Introducció}

La participació de la ciutadania en la vida social, política i cultural d'una societat és un dels elements que sustenten la democràcia. La participació, com a factor que contribueix a millorar la qualitat de vida de les societats, aportant capital social, activant vincles entre les persones i augmentant la legitimitat política de la presa de decisions (Díaz García, 2015), esdevé també una pràctica que millora les capacitats dels individus que conformen aquestes societats.

D’acord amb Benedicto i Morán (2002), és en la joventut quan s'incorporen els recursos necessaris que fan possible l'exercici de la ciutadania i la participació, amb el reconeixement formal i subjectiu de drets i obligacions, i amb l'adquisició de competències necessàries per sentir-se part d'una comunitat, per actuar davant de les institucions socials i dels altres, aspectes que passen per la implicació del jovent en contextos participatius.

Aquesta adquisició de pràctiques i processos participatius en el jovent podria estar afectat i condicionat per l'estat de precarietat que pateix la joventut, i que s'ha agreujat especialment des de l'inici de la crisi econòmica de 2008 , de la qual no es va arribar a recuperar en termes socioeconòmics, i que ara s'ha lligat a una crisi encara més profunda en els seus efectes econòmics, socials i laborals: la de la Covid-19.

En el present article ens proposem analitzar la situació sociolaboral de la joventut, així com l'evolució de les polítiques públiques en l'àmbit juvenil, i especialment analitzem les conseqüències en el desenvolupament $i$ la participació dels joves, considerant l'empitjorament evident tant de la situació socioeconòmica com de la inversió en política pública. L'estat de precarietat juvenil i de les polítiques de joventut influeix en la qualitat de la participació juvenil? Les persones joves en situació precària tenen més o menys possibilitats, voluntat o capacitats per participar en la vida social i collectiva? Aquestes són les preguntes que susciten la investigació.

Per abordar aquestes qüestions i altres reflexions associades a les conseqüències de la precarietat en l'estat personal i collectiu de la joventut, així com l'efecte en la seua pràctica i vivència participativa, analitzem, en el context del País Valencià, les xifres macroeconòmiques del context 
juvenil, i també el paper d'unes institucions públiques que no acaben de respondre a la millora de les condicions vitals de la joventut. Per escometre les conseqüències en la joventut a l'hora d'involucrar-se i participar en el seu entorn, en l'àmbit collectiu i institucional, partim d'una investigació bibliogràfica i del testimoni de quatre persones joves en estat precari (Àlvar, home, 20 anys, estudiant de Magisteri i professor de classes particulars; Montse, dona, 21 anys, TASOC; Robert, home, 23 anys, dissenyador gràfic; Raquel, dona, 20 anys, estudiant de Filosofia i treballadora a temps parcial), totes involucrades en diferents espais collectius. Considerem en aquest article, a l'efecte de la joventut, les persones compreses entre els 16 i 30 anys, d'acord amb les anàlisis i fonts de les dades, així com amb les legislacions autonòmiques i estatals en la matèria.

\section{La precarietat de la joventut i la política juvenil precària: condicionants per al desenvolupament personal i social de les persones joves}

La precarietat és un estat de manca de seguretat i estabilitat laboral (Standing, 2013) en la qual hi ha absència d'un o diversos elements que constitueixen l'estabilitat laboral: seguretat de trobar feina decent, protecció enfront d'acomiadaments o regulacions arbitràries, seguretat per poder promocionar-se o moure's, prevenció de riscos laborals, formació i aprenentatges garantits, salaris estables i adequats, i representació collectiva.

Aquesta precarització impacta de manera directa en àmplies capes i grups socials, i més concretament en la joventut com a grup social d'edat, on s'evidencia des de fa dècades, i de manera més acusada des de l'inici de la crisi econòmica de 2008, que les trajectòries d'inserció laboral lineals tradicionals en la joventut han deixat pas, en el marc d'una societat clarament postindustrial, a un ventall molt més ampli i variat de trajectòries, moltes caracteritzades per la discontinuïtat i per un dèficit d'inclusivitat (Giménez Gual, 2003).

Factors com mileurisme, beques sense seguretat social, contractes temporals i de formació, i les agències de treball temporal, eren ja conceptes recurrents en l'escenari precrisi, que feien cada vegada més difícil 
disposar de condicions de treball dignes i estables, i més encara accedir a un habitatge digne i consolidar projectes emancipadors (Alonso Benito i Fernández Rodríguez, 2008).

Per tant, ja abans de l'inici de la crisi de 2008 , ens trobem amb persones joves que s'incorporen cada vegada més tard i confuses al mercat laboral, mitjançant dubtoses beques o pràctiques en empreses, amb contractes de prova interminables que acaben amb un acomiadament gratuit, amb la frustració i inseguretat econòmica que comporta, incapaces de projectar el desenvolupament d'una carrera o d'un projecte vital (Standing, 2013).

Les dades sociolaborals de la joventut valenciana ja indiquen una situació prèvia a l'inici de la crisi (a finals de 2007) vinculada a la manca de feina estable (el 52,6\% dels contractes a joves eren temporals), i ingressos insuficients (el salari mitjà jove es trobava en $878 €$ ), elements que posterguen la construcció d'itineraris vitals propis en un context associat a la dependència familiar $i$, en el cas de les poques persones joves que es podien emancipar (només el 36,3\% abans dels 30 anys), marcat per una o més formes de precarietat. ${ }^{1}$

Aquesta situació es va agreujar, de manera molt evident, durant la crisi econòmica, i les dades respecte al segon semestre de 2019 (les últimes abans de la irrupció de la crisi sanitària, social i econòmica de la Covid-19), ens mostren un panorama general de més precarietat juvenil en tots els indicadors: més desocupació (un 23,3\%, deu punts més), més temporalitat (59,3\%, set punts més) i salaris insuficients (salari mitjà jove de $881 €$ ). És important ressenyar que la comparativa la fem en un moment, a finals de 2019 , en què s'afirma, en l'àmbit polític, econòmic i social, que la crisi està totalment superada, i que les xifres macroeconòmiques i d'ocupació ho demostren. La realitat és que, pel que fa a la joventut, la situació era, en tots els indicadors, pitjor. D'aquesta manera, amb les dades de finals de 2019 , només un 19\% de joves s'emancipen abans dels 30 anys, pràcticament la meitat que abans de l'inici de la crisi. ${ }^{2}$

I Dades de l'Observatori d'Ocupació del CJE: Comunitat Valenciana, 3r trimestre de 2007. 2 Dades de l'Observatori d'Emancipació del CJE: Comunitat Valenciana, 2n semestre de 2019. 
Aquesta dificultat creixent per emancipar-se indica l'empitjorament de les condicions materials i socials de les persones joves. Una dada que resumeix aquesta situació té a veure amb la pobresa: la joventut és el collectiu d'edat més pobre de tota la societat, i una de cada tres persones joves (el 33,3\%) és pobra, al País Valencià.

La regla generalitzada és, per tant, la dependència de l'economia familiar i la inestabilitat laboral a l'inici de la vida laboral, que tindrà conseqüiències durant les seues trajectòries de vida, fet que es denomina efecte cicatriu (Olías, 2019). Aquesta vivència de la precarietat es pot identificar en la percepció de la joventut mateix:

Nos han dejado una educación que hay que comprar a plazos (créditos), mercado inmobiliario que nos impide el acceso a una vivienda decente, sistema financiero que no nos ofrece ninguna posibilidad, tener que elegir entre empleo de mierda o ningún empleo (Standing, 2013).

Tenim, per tant, unes generacions de joves que han viscut en crisi permanent, i que han vist com, mentre els mercats i institucions anunciaven l'arribada de la "recuperació", les seues perspectives no són gaire encoratjadores (Olías, 2019). Ho hem vist, de nou, amb les primeres conseqüiències de la crisi econòmica derivada de la pandèmia de la Covid-19, les dades de la qual apunten que la destrucció d'ocupació ha afectat, de nou, de manera més directa la població jove ocupada. La desocupació entre menors de 25 anys es va disparar en el conjunt de l'Estat, i va passar d'un $14 \%$ abans de la Covid-19 a un 40\% en el primer trimestre de 2021 (Clavería et alii, 2021). Es tracta de l'última evidència que l'espai laboral expulsa amb més facilitat les persones joves, dificulta trajectòries estables i els condemna a la fragilitat.

En aquesta anàlisi de la situació socioeconòmica de la joventut s'ha de considerar, també, el paper de les institucions i administracions públiques. Quan observem quina ha sigut l'aposta pública quan la joventut ho requeria més, la conclusió és que l'administració s'ha comportat com la mateixa situació juvenil durant la crisi, és a dir, agreujant la seua situació precària. Parlem de precarietat institucional, pel que fa a les polítiques de joventut o de suport a la ciutadania jove, perquè han estat insuficient- 
ment finançades, poc organitzades i no han comptat amb un suport clar dins de l'engranatge públic.

El que ens trobem quan analitzem el paper dels poders públics és un marc institucional que hauria de proporcionar eines per facilitar l'accés al mercat de treball, a l'habitatge, o l'acompanyament en processos participatius, però que en la pràctica no ha oferit solucions als problemes de la joventut com a collectiu (Benedicto i Morán, 2003b), que ha sigut poc sòlid pel que fa a la millora de les condicions de vida de la joventut (Santos Ortega i Martín Martín, 2012), i que ha incidit poc en els aspectes nuclears d'aquestes condicions (Soler Masó et alii, 2013).

Exemplificant en el País Valencià el tractament de la inversió en polítiques de joventut en l'àmbit autonòmic durant la crisi, podem comprovar com la retallada del pressupost global de l'Institut Valencià de la Joventut $(\mathrm{IVAJ})^{3}$ va ser del 40\%, ja que va passar d'una inversió de 17,3 M€ en 2008 a 10,3 M€ en 2013 i 2014. Aquestes retallades van afectar greument la capacitat de l'Institut, com a organisme públic, per poder desenvolupar polítiques concretes.

A més, si atenem als programes concrets de l'organisme, veiem com la retallada va ser encara més elevada, del $87 \%$. És a dir que, durant la crisi, l'organisme de la Generalitat Valenciana responsable de les polítiques de joventut va mantenir, bàsicament, el seu personal fix i les seues depeses administratives, i va suprimir, pràcticament, totes les partides que implicaven programes i línies de subvenció per promoure diferents polítiques de joventut, entre les quals l'associacionisme juvenil i la participació, la mobilitat o diferents assessoraments.

Aquestes retallades en els programes de joventut responen a eixa visió de la política de joventut com a "secundària" o "no essencial", però tenen conseqüències en els processos d'emancipació juvenil, en els projectes i estratègies per afavorir la ciutadania activa entre la joventut, i en estratègies conjuntes amb altres departaments pel que fa a polítiques d'educació, inclusió social, salut o habitatge. Les retallades en les polítiques de joventut valencianes només van ser revertides, per primera vegada, en el pressupost de 2019, i per això ja acumulen més de deu d'anys d'insufici-

3 Pressupostos de la Generalitat Valenciana:<https:/hisenda.gva.es/va/web/presupuestos>. 
ència i retard en el seu desplegament, precisament en una situació en la qual eren especialment necessàries.

Aquesta austeritat en els programes de joventut ha tingut conseqüències professionals respecte de les persones que desenvolupen treball social amb joves. La recensió de contractes, l'ampliació de competències d'altres àrees per estalviar recursos o la reducció de jornades han afectat greument les intervencions en joventut, que es redueixen, i que dificulten o impossibiliten la realització de projectes amb recursos públics, i eixos projectes deriven cap a la privatització o directament se suprimeixen.

Dins d'aquests programes, destaquen els que s'adrecen al suport al teixit associatiu juvenil. El suport a l'associacionisme i la participació juvenils va sofrir una retallada de prop del $67 \%$, i el mateix cas van sofrir tant el Consell Valencià de la Joventut, amb una retallada de més del 70\%, com els Consells Locals de Joventut, que van veure minorada en més d'un $50 \%$ la línia de suport a la seua activitat, que fins i tot va desaparèixer l'any 2012, encara que va tornar a aparèixer en 2013.

D’alguna manera, com afirmen Planas Lladó et alii (2014), la imposició de les retallades i l'austeritat ha fet que el discurs sobre les polítiques integrals de joventut que començava a incorporar-se en l'administració en la primera dècada del segle xxi a Espanya no s'haja correspost amb la pràctica, que s'ha basat en l'escàs impuls a millorar les condicions de vida de les generacions joves.

\section{Conseqüències per al desenvolupament personal i social en persones joves, i de la seua participació}

La principal causa de la situació de precarietat permanent que impacta en la joventut és la consolidació d'un mercat laboral basat en feines amb poca protecció, poques expectatives i baix salari, amb la consegüent acceptació de condicions de treball cada vegada menys dignes.

En els discursos juvenils, quan es parla sobre les condicions laborals en el present, són acceptades amb resignació o fins i tot se celebren com a positives, i s'assumeix el marc de la precarietat estructural. 
Robert, 23 anys:

M'estan pagant en negre... encara no m'han pagat, no sé si me pagaran... eh... i me van dir «horari normal» [...] De 9 a... hui he eixit a les 19 [...] Em van dir que em pagarien el transport i el menjar, que el primer dia va ser cert, i a partir d'ahí ja ha sigut [...] «Bueno, va, pues vos deixe mitja horeta, aneu al Mercadona, pilleu el que vulgueu i torneu» [...] Tinc que pagar-me el piso i... i... 1 euro l'hora és millor que o euros l'hora... sí, les condicions són molt roïnes.

Raquel, 20 anys:

No sé si eren 450 euros «limpios» al mes per treballar 4 hores al dia, de dilluns a divendres. [...] Bé, la veritat és que ja te dic que jo d'açò no tinc molta idea però la veritat és que jo no vaig considerar ni que cobrara menos ni que estiguera més desagust.

Aquesta vivència de la precarietat condueix la joventut a un sentiment de degradació generalitzat, marcat per l'absència de perspectives socials per al seu futur, per la desregulació de les trajectòries vitals i de desestandarització d'itineraris biogràfics, amb un trencament amb els models anteriors de pas a projectes de vida independents i un desmantellament de les estructures laborals, habitacionals, econòmiques, polítiques i socials que facilitaven eixos itineraris (Santos Ortega i Martín Martín, 2012).

Montse, 21 anys:

Estic en vàries webs de feina, ademés de tirant currículums a lo loco, en tot el que em trobe [...] Sobretot temporal. Sobretot substitucions

Àlvar, 20 anys:

He treballat [...] donant repassos, perquè estic còmode, me mola, i m'ho puc permetre [...] treballe prou en el sentit que faig 3 o 4 hores al dia [...] Pel meu compte. Tot... tot en negre. I després he treballat [...] posant valles [...] Considere que les condicions no em puc queixar comparat en com estan en altres... 
Giménez Gual (2003) entén l'emancipació com l'adquisició de la capacitat d'autodeterminació o decisió sobre l'evolució de la vida mateixa. La joventut no compta, en aquest sentit, amb les condicions necessàries per emancipar-se, ja que fer-ho com a membre de la ciutadania implicaria decidir plenament i amb autonomia i independència la trajectòria vital.

Àlvar, 20 anys:

És súper fotut... ara... per als joves [...] el plantejar-te viure fora [...] si ja és difícil tindre una casa de per si, com... com a persona normal, imagina't ja com a jove.

Més enllà de l'emancipació, altres conseqüències, menys visibles, estan configurant un model per a la joventut marcat per la pèrdua de control del temps, per l'individualisme i per l'apatia, aspectes que afecten directament les possibilitats, motivacions i capacitats de les persones joves per participar en la vida social i collectiva.

Robert, 23 anys:

Durant la carrera moltes vegades era en plan... te despertaves a les set, eixies de classe a les 14, i de 15 a 21 treballaves amb l'ordinador, i jo me deia a mi mateix: «no passa res, quan treballe d'això no m'hi dedicaré la meitat del dia», i... hui he entrat a les 9 , i he eixit a les 19, cobrant 1,67 $€$ l'hora.

Àlvar, 20 anys:

Comences a treballar, i no pares, o siga... i t'enganxa eixe cicle [...] vius en eixa roda constant de «de 8 a 2, classes, i de 5 de a 8 repassos, i a dormir, i altre dia» [...] no sé fins a quin punt ho faig per plaer [...] o igual ho faig moltes voltes perquè he entrat en eixa roda de treball assalariat de guanyar pasta.

Els joves tenen molt difícil mantindre un control del seu temps. D'acord amb Standing (2013), hi ha una sèrie de pressió sobre el temps, no només de treball, sinó de formació, de recerca de feina, de treball reproductiu, que generen tensió, i que s'uneix a la vivència del treball, amb condicions insegures, remuneració incerta i alt cost d'oportunitat. Aquesta dificultat per gestionar el temps té un impacte directe en l'accés a les condicions de ciutadania. Aquesta pèrdua de control del temps impacta en el temps 
disponible d'oci, ja que la diferenciació entre l'espai de feina o formació productius i l'espai de descans i oci, que abans estava prou delimitada, ha desaparegut a causa, d'una banda, de l'extensió del temps no-oficial de feina i, de l'altra, de la precarització de les relacions laborals i de la condició laboral. En els discursos s'observa com el temps és un impediment per a l'exercici de ciutadania activa, participació collectiva i dedicació:

Robert, 23 anys:

No vivies millor, perquè vivia molt estressat i no ho sabia [...] fent feina de la uni tots els findes, i quan vaig començar a treballar no, o sea que me podia anar per ahí els caps de setmana, eh... i entre setmana, ben poca, perquè acabaves a les 5 i mitja... arribaves ací a les 6, 6 i quart, l'únic temps que em donava és a llegir un poc un llibre o eixir a córrer, ja està...

Àlvar, 20 anys:

Recorde una volta que estava donant un repàs a... a un xiquet, un només perquè tenia un examen, i pues vaig dir: «pues ens quedem més rato», i recorde que després tenia una reunió... i... i hòstia, me'n recorde que no tenia suficient temps per anar a casa i fer-me el sopar, aleshores vaig passar per un kebab, em vaig agafar el sopar, i tot el que havia guanyat en eixa hora de més que havia fet m'ho havia gastat en el sopar... que jo crec que és la metàfora de... d'esta societat en la que vivim.

Montse, 21 anys:

En la feina que tinc, soles m'ocupa... pues 3 hores entre que vaig, vinc i estic en la feina [...] I la vesprada eh... és oci, i al mateix temps, no. Clar, jo ho considere més oci que no, perquè estic en una escola de música [...] però al mateix temps és feina realment [...] feina no, no remunerada, però feina.

Raquel, 20 anys:

En un mes normal [...] pues perfectament podria tindre un mínim de tres o quatre reunions setmanals amb el Consell més [...] entre dos i quatre reunions setmanals de [...] la meua entitat [...]. En reunions, a lo millor a la setmana [...] entre 10 i 15 a lo millor [...] i després a part els caps 
de setmana en els que fem activitats, tenim assemblees [...] però me puc tirar pràcticament tot el cap setmana.

Una de les conseqüències derivades de l'anàlisi anterior és la fragilitat de xarxes estables per a una participació més enllà de la individualitat, i l'abandonament d'aquests espais quan el context sociolaboral o econòmic es torna complex.

Montse, 21 anys:

Quan em vaig clavar als cicles... la bofetada de realitat va ser molt gran [...] a nivell de càrrega de continguts i càrrega de treballs [...] em vaig deixar l'orquesta i la flauta [...] Va ser difícil, la veritat, perquè després aplegaves a casa [...] m’entrava com, no sé...algo, «jo... jo vull anar».

Àlvar, 20 anys:

Jo... primer de tot que la militància sovint és veu com algo molt... molt passatger [...] i després ja la vida et condiciona en certa manera: «ah no, és que jo he de buscar curro, he de buscar parella, una hipoteca, un casa, un cotxe...» $\mathrm{i}$ ja no veus com la militància que te traspasse, o siga, dia rere dia, no... no ho veus així.

El precariat no té control sobre el seu temps i, en conseqüència, opera a curt termini, per una incapacitat de planificar a llarg termini, la qual cosa implica una baixa probabilitat per progressar. En la joventut es consolida una cultura caracteritzada per "ací i ara», i per la recerca d'interessos particulars amb immediatesa (Grupo de Investigación Psicosoc, 2011). La manca de control del temps fa que la joventut s'allunye d'aquells àmbits, tasques, espais, projectes i ocis que suposen dedicació, constància i implicació a llarg termini, i opte per espais de socialització en el temps lliure vinculats a l'oci de consum, on les tecnologies de la informació i comunicació ocupen un espai central (Giménez Gual, 2003). Aquesta forma d'oci i de relació amb el grup de parells es prefereix enfront d'activitats culturals, tot i que la cultura de música, pellícules i sèries hi és present (Canal Rodríguez, 2014), sempre condicionada a la immediatesa, amb una descàrrega i un consum al moment. 
La limitació del temps disponible esdevé una clara dificultat per poder participar, per poder vincular-se a projectes collectius i per poder involucrar-s'hi a llarg termini.

Àlvar, 20 anys:

S'ha convertit una mica en el [...] meu oci [...] no tinc oci com a tal [...] els dos primers anys estiguí de coordinador [...] duia jo l'associació, bàsicament, i això també és una càrrega [...] és prou fotut a nivell emocional, perquè això nosaltres també ho traiem moltíssim, el tema de les cures, l'estar còmode i tot... [...] me falta temps [...] Tinguí un atac d'ansietat.

Raquel, 20 anys:

Recorde l'època en la que vaig estar treballant, que també estava estudiant i també estava en el Consell i en el Consell de Castelló també, i en FAAVEM [...] i jo no podia amb tot [...] és un temps en el que no tens temps per a fer res més. [...] va haver setmanes que anava molt agobiada.

Montse, 21 anys:

Vaig estar a punt d'entrar en la junta l'any passat [...] Però... va ser quan vaig començar les pràctiques i tot això, i era massa. Classes, pràctiques, més classes... era massa jaleo, entonces igual l'any que ve... a lo millor, no ho sé. Sí que voldria.

Robert, 23 anys:

Jo diria que hi ha coses que s'escapen del meu control [...] estic sobre la pressió de dir... tampoc tens tu tot el temps del món per a posar-te a... de forma súper activista a fer coses perquè tens una feina, $i$ ja vius amb prou d'estrès com per a, ara, tirar-te tot el dissabte i tot el diumenge també fent coses...

Aquest temps sense control, unit a les dependències econòmiques $\mathrm{i}$ vitals, afecten clarament la capacitat de participar i d'involucrar-se en projectes autònoms. 
Àlvar, 20 anys:

Jo tinc molts companys que no militen per curro [...] no els dona la vida [...] em recorde d'un company que... està en el collectiu del poble, que l'únic que fa és pagar, perquè... li sap mal no poder participar, però és que està de pluriempleat perquè treballa pels matins [...] de mecànic, $\mathrm{i}$ per les nits en el kebab, o siga, repartint i tot...

La immediatesa, pèrdua de control del temps i el pensament a curt termini influeix en els projectes vitals: les relacions, la participació en la vida social, la manera d'organitzar el temps, ja no es vehicula qüestionant-se la direcció i valor que tenen, sinó quant de temps duraran. En paraules de Garcés (2017), passem de preguntar-nos «cap a on» a preguntar-nos «fins quan»:

Fins quan tindré feina? Fins quan viuré amb la meva parella? Fins quan hi haurà pensions? Fins quan Europa continuarà sent laica, blanca i rica? Fins quan hi haurà aigua potable? Fins quan creurem encara en la democràcia? Des de les qüestions més íntimes fins a les més collectives, des de l'àmbit individual fins a l'escala planetària, tot es fa i desfa sota l'ombra del «fins quan» (Garcés, 2017).

Ens trobem en un context en què les condicions i perspectives vitals són cada vegada més inestables, i també ho acaben sent les nostres xarxes d'amistats i familiars, la posició social en la qual ens trobem, i l'autoestima i la confiança en nosaltres mateixos que en deriven (Bauman, 2017). Es produeix una erosió dels processos d'interacció relacional entre les persones, afectades per les necessitats personals, socials i, fins i tot, les fisiològiques, que impacten en la nostra motivació cap a allò colllectiu.

Els entorns de flexibilitat i inseguretat posen en perill la predisposició que tenim les persones per confiar i cooperar (Standing, 2013), ja que els individus temen comprometre's o involucrar-se en pautes de comportament a llarg termini. Les persones joves, en aquest sentit, no desitgen veure's encadenades per projectes compartits que puguen suposar una vinculació econòmica o generen una dependència temporal que puga pertorbar encara més el descontrol sobre el temps disponible. 
S'està donant lloc, fruit de la situació precària de la joventut, a una creixent individualització i a una competitivitat entre les persones, aspectes que afecten directament la voluntat per involucrar-se en projectes collectius i per participar en la vida social i comunitària.

Robert, 23 anys:

O sea jo vaig a la meua puta bola, però hi ha gent que... que... que està com molt fora de tot, i li dona igual tot, i sí que considera que la seua acció no té res a veure amb res... [...] Altra gent, també l'entenc, que si està treballant de dilluns a divendres, vol el temps per a ell, no?

Hi ha una tendència que cada persona assumisca les seues trajectòries com a conseqüiència directa de les seues opcions i actes, és a dir, com a èxits i fracassos personals (Giménez Gual, 2003), és a dir, una individualització dels riscos, sense tindre en compte el context socioeconòmic i les dificultats que genera, sense basar-se en una xarxa relacional que done suport, i sense plantejar-se una resposta o solució collectiva als problemes.

Raquel, 20 anys:

Entenen que jo prenga les meues decisions i que si jo vull estudiar filosofia i, segons ells, maacaba eixint mal, pues que les conseqüències les acabaré pagant jo.

Açò contribueix encara més a la fragmentació de les estructures socials, al debilitament de les identitats collectives i a la pèrdua de la noció de classe. A més, d'aquesta individualització se'n desenvolupa l'egoisme que impregna la societat de hui dia, el de collocar el jo i les meues comoditats davant de tota decisió (Trueba, 2018). Eixa individualització del risc pel que fa a la dimensió collectiva de la vida (Giménez Gual, 2003) comporta un debilitament de vincles interpersonals i la pèrdua d'identitats collectives.

Robert, 23 anys:

Quan anàvem a netejar el riu, i al dia següent estava brut perquè venia un camió... pues jo després de veure això, ja em costava molt tornar a netejar el riu, perquè era en plan «per què vaig a estar netejant el riu, si després van a vindre i van a [...] embrutar una altra vegada?» [...] ex- 
trapolant-ho a manifestacions i totes estes coses [...] considere que no... serveixen... que... que és dins de tota la hipocresia del món, no? Però [...] no veig resultats immediats [...] passe, saps?

Lestat de fragilitat i debilitat que es deriva de la precarietat i que impedeix que les metes, expectatives de vida i anhels es realitzen genera una frustració existencial constant que envaeix cada moment i cada activitat (Grupo de Investigación Psicosoc, 2011). Aquesta frustració té en les trajectòries fallides la seua màxima expressió: trajectòries vitals que no discorren tal com s'havien projectat per part de les persones joves, o el retorn a la llar familiar, el que es coneix com a trajectòries io-io, o boomerang kids (Santos Ortega i Martín Martín, 2012). Es tracta del «fill bumerang» que torna a casa després del procés educatiu i s'afona en la letargia, treballs a temps parcial, deutes, drogues i puntuals desitjos de «viatjar» (Standing, 2013).

Aquestes trajectòries fallides o anullades i la frustració que se'n deriva generen un estat d'apatia en la joventut: una passivitat nascuda de la desesperança, influïda pel temor a perdre el poc que es posseeix (Standing, 2013).

Robert, 23 anys:

Eh... i no res, i quan vaig acabar la carrera vaig tornar al poble, sobretot perquè com el pis... pues no podia seguir, no podia pagar-me-lo perquè no tenia feina, vaig tornar al poble.

Generen subjectes que no volen eixir de la seua bombolla de comoditat i seguretat immediata, i que prefereixen romandre fragmentats i aïllats en la seua fragilitat i debilitat (Alonso Benito i Fernández Rodríguez, 2008).

Robert, 23 anys:

Fa dos anys no, i volia fer més, i ara [...] m’autoconvenzo, o m’automiento i digo: «de moment, soluciona el teu cap i després ja miraràs si pots fer alguna aportació».

La situació de precarietat consolidada en la qual està immersa la joventut i l'absència d'unes polítiques de joventut amb el pressupost i personal suficient per actuar amb profunditat tenen conseqüències en 
la cultura participativa de les persones joves; en la definició dels valors, actituds i dinàmiques propis de la ciutadania activa.

A banda de les dependències econòmiques i la manca de control del temps, hi ha factors socials i polítics, vinculats a les vies, espais i estructures de participació, que afecten la participació juvenil. Trobem, en aquest sentit, uns processos de participació, basats en una alta reglamentació i acreditació de processos, que exigeixen a les persones que hi prenen part experiència, coneixement dels codis, aportació de garanties, estabilitat en el temps (Francés García, 2008), factors que generen una distància i dificulten l'accés a persones immerses en dinàmiques vitals inestables $\mathrm{i}$ mòbils.

Àlvar, 20 anys:

Que quan ens posàrem amb la burocràcia, que n'hi ha per a legalitzar-se i tot, diguérem: «mare de Déu, açò què és?». [...] recorde que férem tots els papers [...] que si els estatuts, que si no sé què [...] però això ens desgastà de tal manera... [...] i al final ho deixarem... de banda.

Hi ha una limitació i, en molts casos, manca d'aposta de les administracions i entitats públiques per a la generació de processos participatius que realment involucren les persones:

Montse, 21 anys:

En relació a participació poc [...] perquè fan coses perquè la gent participe però... però de forma expectant [...] moltes coses de... de «sí, vull que participes, però senta't i escolta'm» o de «vine a mirar» o... saps? No de participar realment.

Àlvar, 20 anys:

M'he deixat el sindicat este any, per exemple, a nivell universitari [...] no donen les ferramentes necessàries per a participar, $i$ tampoc els interessa.

Si a això hi sumem les retallades generalitzades sofrides en les estructures, organismes i processos participatius, especialment de joventut, i en les figures tècniques d'acompanyament de joves per a la participació 
en aquests processos, el resultat es troba en una disminució de la participació juvenil en aquestes vies i estructures.

Àlvar, 20 anys:

No n'hi han espais de convivència [...] la regidora de joventut... ens digué que n'hi havia un superàvit [...] una animalà de diners, vull dir... en la vida. Però no, no n'hi ha diners per a invertir-los en, en un local jove... [...] Per a nosaltres les institucions, ja te dic, han sigut, [...] més traba que... que no ens han facilitat mai, mai res.

Com a conseqüència, les condicions personals minvades cap a la participació estable i d'uns espais de participació altament burocratitzats i amb poc suport, la participació juvenil es desplaça, ja des de fa temps, cap a contextos informals, més vinculats a espais quotidians (Francés García, 2008), i no tant cap a projectes a llarg termini.

La participació es desplaça cap a esferes comunitàries, amb nous marcs organitzatius, més instrumentals. Un exemple el trobem en els moviments socials sorgits en els últims anys, caracteritzats per presència juvenil, i per una flexibilitat d'estructures, assemblearisme, més adaptació a ritmes i formes de vida actuals, $\mathrm{i}$ amb identitats pròpies de societats postindustrials (Giménez Gual, 2003).

Àlvar, 20 anys:

Junt a dos o tres collegues [...] em recorde que en tercer vam muntar un collectiu antifeixista ací en València [...] érem quatre gats, molt joves [...] en eixa plaça me'n recorde que una vingué amb ordinador, clar, per a prendre acta, i jo en eixos moments, vull dir, és quan aprens a prendre acta i tot [...] era una experiència molt nova [...] a l'any següent diguérem: «amo a muntar un collectiu antifeixista en el nostre poble», i el muntàrem.

Raquel, 20 anys:

Els moviments actuals sobretot estan liderats per, per joves, com per exemple Fridays for Future o entitats, moviments, a lo millor el moviment feminista ara també engloba moltíssima gent jove, molta gent ara està empoderant-se en el sentit de participar. 
Robert, 23 anys:

A nivell mediambiental [...] dissabtes i diumenges, vam netejar una zona de riu per fer una platja i tal... això va estar molt guai. [...] em vaig enterar per Facebook, o sea, em vaig presentar i avisar, no coneixia ningú.

La reducció de temps disponible i l'absència d'escenaris de futur provoquen pràctiques participatives vinculades a metes més immediates, realitzables i assolibles (Francés García, 2008). Els projectes, per tant, són a curt i molt curt termini, molt aferrats al present, i donen lloc a formes poc institucionalitzades de participació, més individualitzades i reivindicatives (Planas Lladó et alii, 2014). Les motivacions per participar són més utilitaristes (Aguado et alii, 2011), consoliden uns estils participatius marcats per la desafecció, no convencionals (García Albacete, 2008), i desvien el potencial cap a activitats estrictament socials, d'oci, o vinculades a la «nova política» (Benedicto i Morán, 2003b).

Els moviments de protesta i reivindicació més espontanis i reivindicatius que sorgiren al començament de la dècada per denunciar condicions d'explotació en diferents àmbits, com ara el Moviment 15M o Juventud Sin Futuro (Santos Ortega i Martín Martín, 2012), van esdevindre el revulsiu per a una nova lluita de classes, l'apropiació per part de la joventut dels seus drets sociopolítics i la demanda d'unes condicions materials de vida decents. Aquests moviments estaven conformats per joves a qui afectava la crisi de primera mà, i reclamaven solucions a necessitats bàsiques com l'ocupació o l'habitatge per poder emancipar-se (Planas Lladó et alii, 2014). Són moviments, però, més inestables, amb menys trajectòria, per la inestabilitat que marca el context socioeconòmic de les persones que en formen part, i per la fragilitat de les estructures, al marge la pràctica participativa institucionalitzada, en què es mouen.

Àlvar, 20 anys:

Fou l'any de la LOMQUE [...] muntàrem la xarxa d'instituts [...] pels quatre pipiolos que érem férem una concentració que te cagues [...] eixa experiència fou guapíssima. Damunt me molà molt perquè ho capitalitzàrem la gent del poble [...] fou una de les experiències més xules. [...] fou una llàstima, perquè faltà [...] un relleu generacional... i també perquè al final estos moviments el que passa és que hi ha molta indignació en eixe 
moment, i si no saps canalitzar-la bé [...] es queda en un moviment... espontani d'eixe moment.

D'aquest impuls de l'«ara o mai», fruit del desdibuix del futur, naixen els moviments en els últims anys, de protesta, d'autoorganització de la vida en comú, d'intervencions en les guerres i contra les guerres, de transició ambiental, de cultura lliure, i els nous feminismes (Garcés, 2017). Moviments que sorgeixen, d'una banda, perquè la seua existència al marge de canals tradicionals permet més flexibilitat, immediatesa, desregulació d'estructures d'acord amb els interessos i disponibilitat de les persones que hi participen, i, de l'altra, per l'immobilisme de les estructures públiques i de certes estructures associatives, que continuen operant amb una visió adultocràtica que espera que les persones joves s'hi adapten mitjançant l'assimilació de les seues formes i els seus tempos.

Àlvar, 20 anys:

Lajuntament no fa les coses bé. [...] Al final l'oci està en la ciutat [...] en el poble no n'hi havia res, i tens dos opcions [...] o bous al carrer, o unflar-te a porros en el parc, i després dels porros moltes voltes acabes en la discoteca i unflar-te a cristal [...] installacions esportives res, no n'hi ha oci, segueix sense haver, després de 8 anys de governs, en teoria, progressistes o dis-li com vulgues, no n'hi ha una alternativa d'oci potent, a banda de la que donem nosaltres.

La modificació d'aquestes estructures o el seu replantejament estan limitats per factors que hem analitzat: les retallades en programes de joventut han disminuït considerablement les capacitats de les entitats i estructures de participació de replantejar-se canvis en el model, ja que han estat, i estan, més centrades a garantir la seua supervivència.

Àlvar, 20 anys:

Dels Consells Joves i totes estes coses, moltes voltes, es busca dirigir-los des de les institucions [...] pense que no funcionen moltíssims perquè no se'ls dóna a la gent jove la capacitat d'autoorganització, que és bàsica. 


\section{Conclusions}

Ens trobem amb un conjunt de factors socioeconòmics i institucionals que estan generant un escenari de precarietat amb greus efectes en la joventut, com a grup d'edat social més feble i vulnerable (Soler Masó et alii, 2013). Aquests factors, com hem observat, operen no solament en l'àmbit sociolaboral, sinó també en l'àmbit vital. No parlem només de precarització de l'espai laboral, sinó d'una precarització de la vida (Alonso Benito i Fernández Rodríguez, 2008).

Aquests factors, com hem analitzat, impacten en les capacitats transformadores de la joventut, que veu limitada la seua acció participativa, portada, de manera inevitable, a un qüestionament, a autoinculparse de la seua situació, s'autoexclouen dels assumptes i espais, i observen com a espectadors desinteressats en lloc d'assumir una postura crítica (Agudo et alii, 2011).

Assistim, en conseqüència, a un afluixament dels vincles humans, provocat per eixe desmantellament creixent de les possibilitats i mecanismes que tenim per relacionar-nos i defensar-nos collectivament (Bauman, 2017), fet que ens condueix a l'individualisme i a preocupar-nos només per la nostra immediatesa, i a deixar de banda assumptes collectius, renunciant a la participació:

Parece que hemos dejado de tener el control como individuos, como grupo y como colectivo. Para empeorar aún más la situación, carecemos de las herramientas que puedan elevar la política hasta el lugar en el que ya se ha instalado el poder, algo que nos permitiría reconquistar y recobrar el control de las fuerzas que conforman nuestra condición compartida, y definir así nuestro abanico de posibilidades y los límites de nuestra libertad de elección; un control que en algún momento se nos ha escapado (o nos han arrebatado) de las manos. (Bauman, 2017)

A aquest fet s'hi suma la manca de temps i la incapacitat per organitzar-se la vida a causa de la sobreexplotació laboral, en un context social en què, a més, cada vegada és més difícil gestionar l'excés d'informació que ens bombardeja. Una combinació que dona lloc, en paraules de Garcés (2017), a un «analfabetisme illustrat»: al fet de delegar la nostra intelli- 
gència, és a dir, la nostra capacitat d'acció, i quedar com a observadors de l'esdevenir social.

La renúncia a l'espai collectiu i la delegació de la nostra capacitat d'acció ciutadana, a més d'empobrir la vida comunitària, té importants conseqüències per a la democràcia mateix, provocades per eixa individualització de la vida.

La «limitació» de drets de ciutadania (que, tot i que es conserven intactes en l'àmbit formal, en la pràctica no es poden exercir completament) s'uneix a una pèrdua de respecte a la participació i un privatisme civil, que condueix a un aprimament democràtic i a una mercantilització de la política (Standing, 2013). El distanciament i rebuig de les institucions és un clar senyal d'advertència, unit a l'atracció creixent pels populismes i pels missatges neofeixistes, amb una propensió a donar cabuda a veus extremistes o fanàtiques.

Aquesta deslegitimació de les estructures institucionals transita sobre una creixent pèrdua de control dels processos socials, en favor de poders globalitzats, que impacta directament sobre la construcció d'identitats i la construcció de la ciutadania (Giménez Gual, 2003).

Com es pot respondre a aquests fets evidents que observem? Com es pot afavorir la participació? La resposta es troba en la generació, en l'àmbit local, de les condicions per exercir la ciutadania. Els drets de ciutadania, en paraules de Bauman (2017), estan lligats, tant els personals com els polítics, i només poden ser conquerits junts. La protecció de les persones i la seua seguretat són condicions indispensables perquè puguen lluitar amb eficàcia pel dret a la participació política.

La clau és, per tant, garantir un context on les persones tinguen recursos, disponibilitat i espais perquè les condicions de ciutadania siguen possibles, on es puga generar un procés d'apoderament de la ciutadania, amb especial èmfasi en la joventut com a etapa d'entrada a l'exercici ple dels drets collectius, que generi processos deliberatius que aprofundisquen vincles de reciprocitat, sociabilitat i solidaritat, i afavoreixi la confiança i la connectivitat social (Cefaï, 2003).

La precarietat de les persones joves, ocasionada pel marc social i per la concatenació de crisis, genera una sèrie de tensions a l'hora de participar 
en espais collectius; alhora, les polítiques públiques no acompanyen prou aquesta participació. Les propostes d'actuació possibles haurien d'anar encaminades a revertir les causes per les quals la participació juvenil està afectada, tant a escala socioeconòmica com institucional:

Es poco probable que la salvación provenga de un Estado político que no sea también, al mismo tiempo, un Estado social. Sin derechos sociales para todos, un gran número de personas encontrará que sus derechos políticos son inútiles y carentes de interés. Del mismo modo que los derechos políticos son indispensables para instaurar derechos sociales, también los derechos sociales son indispensables para mantener operativos los derechos políticos. Ambos derechos se necesitan para sobrevivir (Bauman, 2017).

Cal abordar, en conseqüència, tant propostes estructurals com mesures pal-liatives, al mateix temps que ampliem considerablement l'acció de l'administració per garantir estructures i processos participatius, i per millorar sistemes educatius i formatius, competències on les institucions sí que tenen un ampli marge de maniobra.

La clau es troba a impulsar l'autonomia de la ciutadania perquè puga participar en l'esfera pública i reclame el seu protagonisme en els processos sociopolítics, i això passa, en paraules de Benedicto i Morán (2003b), per aconseguir una joventut que hi siga present, que garantisca eixa presència amb un entorn social i econòmic que permeta l'accés i exercici dels seus drets, i una joventut que siga protagonista, que puga intervindre activament i tinga la capacitat d'influir sobre el desenvolupament dels processos socials i polítics. 


\section{Referències bibliogràfiques}

Agudo, Y., Martín, E. i Tovar, F. (2011) Revista Estudios de Juventud, 95.

Alonso Benito, L. E. i Fernández Rodríguez, C. J. (2008) «Jóvenes: precariedad laboral, precariedad de vida» Gaceta Sindical: Reflexión y Debate, 10: 67-84.

BAngo, J. (1991) «Participación juvenil e institucionalidad pública de juventud, al rescate de la diversidad» Última Década, 10: 1-8.

Bauman, Z. (2017) Tiempos líquidos. Vivir en una época de incertidumbre. Barcelona: Tusquets Editores.

BENEDICTO, J. i MoRÁN, M. L. (2002) La construcción de una ciudadanía activa entre los jóvenes. Madrid: Instituto de la Juventud.

Benedicto, J. i Morán, M. L. (2003a) Aprendiendo a ser ciudadanos. Experiencias sociales y construcción de ciudadania entre los jóvenes. Madrid: Instituto de la Juventud.

Benedicto, J. i Morán, M. L. (2003b) «Los jóvenes, ¿̇ciudadanos en proyecto?». A Benedicto, J. i Morán, M. L. Aprendiendo a ser ciudadanos. Madrid: Instituto de la Juventud. 39-64.

Canal Rodríguez, P. (2014) «Recensión: Informe de Juventud en España 2012» Metamorfosis. Revista del Centro Reina Sofia sobre Adolescencia y Juventud: 112-118.

CEFAÏ, D. (2003) «Acción asociativa y ciudadanía común: ¿La sociedad civil como matriz de la res pública?» A Benedicto, J. i Morán, M. L. Aprendiendo a ser ciudadanos. Madrid: Instituto de la Juventud. 91-115.

Clavería, S., García-Albacete, G., López Ortega, A., Torre, M. i Simón, P. (2021). Informe Juventud en España 2020. Madrid: Instituto de la Juventud.

FRANCÉS GARCÍA, F. J. (2008) «El laberinto de la participación juvenil: estrategias de impliación ciudadana en la juventud» OBETS: 35-51.

GARCÉs, M. (2017) Nova il.lustració radical. Barcelona: Anagrama.

García Albacete, G. (2008) «¿Apatía política? Evolución de la implicación de la juventud española desde los años 80» Revista Estudios de Juventud, 81: 133-158.

García Albacete, G. (2019) «Política: producto del tiempo que les ha tocado vivir» Sueños y Pesadillas de la Juventud en España, 25: 18-19. 
Giménez Gual, L. (2003) «Las políticas de juventud: hacia unas políticas emancipatorias». A Benedicto, J. i Morán, M. L. Aprendiendo a ser ciudadanos. Madrid: Instituto de la Juventud. 159-180.

Grupo de Investigación Psicosoc (2011) «El sentido de la vida en los jóvenes: redes sociales, relaciones significativas y actividades de ocio» Revista Estudios de Juventud 95: 59-72.

Llamas SÁNCHEZ, F. (2003) «Jóvenes, desarrollo sostenible y nueva gobernabilidad en lo local: apuntes para un debate». A BENEDICTO, J. i Morán, M. L. Aprendiendo a ser ciudadanos. Madrid: Instituto de la Juventud. 181-191.

López JimÉNez, Á. (2003) «Cultura e indentidades juveniles modernas. Consciencia generacional de los jóvenes españoles». A Benedicto, J. i Morán, M. L. Aprendiendo a ser ciudadanos. Madrid: Instituto de la Juventud. 17-38.

Luque, E. (2003) «Cómo se forman ciudadanos: de la confianza a los saberes». A Benedicto, J. i MorÁn, M. L. Aprendiendo a ser ciudadanos. Madrid: Instituto de la Juventud. 65-89.

Merino, L. (2011) «Jóvenes en redes sociales: significados y prácticas de una sociabilidad digital» Revista Estudios de Juventud, 95: 31-43.

OLíAs, L. (2019) «Trabajo: los que solo conocen la precariedad laboral» Sueños y Pesadillas de la Juventud en España, 25: 20-22.

Pedró, F. (2003) «¿Dónde están las llaves? Investigación politológica y cambio pedagógico en la educación cívica». A BENEDicto, J. i Morán, M. L. Aprendiendo a ser ciudadanos. Madrid: Instituto de la Juventud. 235-257.

Planas Lladó, A., Soler Masó, P. i Feixa Pàmpols, C. (2014) «Juventud, políticas públicas y crisis en España ¿Triángulo mágico o triángulo de las Bermudas?» Revista Latinoamericana de Ciencias Sociales, Niñez y Juventud, 12 (2): 551-564.

SÁnchez Alonso, M. (2000) La participación. Metodología y práctica. Madrid: Editorial Popular.

Santos Ortega, A. i Martín Martín, P. (2012) «La juventud española en tiempos de crisis. Paro, vidas precarias y acción colectiva» Sociología del Trabajo, 75: 93-110. 
Soler Masó, P., Planas Lladó, A. i Feixa Pampols, C. (2013) «Jóvenes y políticas de juventud en tiempos de crisis: el caso de España». A Torío López, S., García Pérez, O., Peña Calvo, J. V. i Fernández García, C. M. La crisis social y el estado del bienestar: las respuestas de la pedagogía social. Oviedo: Servicio de Publicaciones de la Universidad de Oviedo. 347-353. Standing, G. (2013) El precariado. Una nueva clase social. Barcelona: Pasado y Presente.

Trueba, D. (2018) La tiranía sin tiranos. Barcelona: Anagrama. 